\title{
Forage supply systems for dryland dairy farms in southern Australia
}

\author{
D.F. CHAPMAN ${ }^{1}$, J.L. JACOBS ${ }^{2}$, G.N.WARD ${ }^{2}$, G.B. O'BRIEN ${ }^{3}$, S.N. KENNY ${ }^{1,4}$, \\ D. BECA ${ }^{5}$ and F.R. McKENZIE ${ }^{2}$ \\ ${ }^{1}$ School of Agriculture and Food Systems, University of Melbourne, Victoria 3010 \\ ${ }^{2}$ Department of Primary Industries, 78 Henna St. Warrnambool, Victoria 3280 \\ ${ }^{3}$ Department of Primary Industries, RMB 2460, Ellinbank, Victoria 3821 \\ ${ }^{4}$ Faculty of Veterinary Science, University of Sydney, Camden, NSW 2570 \\ ${ }_{5}^{5}$ BecaZuur Consulting Pty, 16 Grange Road, Warrnambool, Vic 3280
}

d.chapman@unimelb.edu.au

\begin{abstract}
Continued improvements in home grown forage consumption are needed to support the long-term profitability of the dairy industry in southern Australia. Most home grown forage currently comes from perennial ryegrass pastures, which have significant limitations in the southern Australia environment. These limitations threaten future productivity gains, and we therefore consider opportunities for using other plant species. Data on the production of alternative perennial grasses, brassica summer crops, C4 summer crops and winter cereals grown for whole-crop silage are limited and generally show large variation in yields between sites and years. Simulation models suggest that, once the base ryegrass pasture is well-utilised, incorporating complementary forages can return $\$ 70$ - $\$ 100 /$ ha extra operating profit for every additional tonne of home grown forage DM consumed per ha. Double cropping (winter cereal or annual ryegrass followed by a summer crop of turnips or maize) and summer-active pastures such as tall fescue show particular promise. Further information is required on how to integrate these forages into whole farm feeding systems to realise the additional profit with manageable business and environmental risk.
\end{abstract}

Keywords: dairy systems, forage production, pastures, forage crops, simulation models

\section{Introduction}

Like New Zealand, the dairy industry in southeast Australia relies on pasture to help control feed costs and maintain profitability. Victoria, Tasmania and South Australia produced 7.9 b litres of milk in 2004/05 accounting for $78 \%$ of Australia's total annual milk production (Anon. 2005). Most of this milk comes from non-irrigated production systems based on perennial ryegrass. Ryegrass offers benefits such as ease of establishment and management, and responsiveness to $\mathrm{N}$ fertiliser inputs. However, in southeast Australia, hot dry summers are the norm and perennial ryegrass does not tolerate these conditions well.

The drawbacks of perennial ryegrass for high producing systems have been exposed by growth in the industry through the 1990s which was associated with increased stocking rates and purchased supplements to support required levels of animal feeding (Fulkerson and Doyle 2001). These drawbacks include strong seasonality in the quality and quantity of feed supply $(60+\%$ of total annual growth in spring) and limited pasture persistence ( $3-5$ years, McKenzie et al. 2006). The outcome for the balance between feed supply and demand at different stocking rates is shown in Figure 1. There are substantial feed gaps in summer even at the lowest stocking rate, and in winter at moderate to high stocking rates.

Forage (pasture plus crops) grown on-farm generally costs less than purchased feed and the average cost of all feeds consumed is closely related to dairy farm profitability in southern Australia. Future industry growth therefore depends upon continued improvement in the amount of home-grown forage consumed in farm businesses. In 2002, the Australian dairy industry launched the project 'Southern Dairy Systems' to "determine and demonstrate how to consistently and costeffectively average more than 20 tonnes DM/ha of highquality feed grown and utilised on southern dairy farms, and the productivity improvements resulting from this". This paper reports the results of desk-top research undertaken to help meet this challenge.

\section{What Do We Have Now? Current Pasture Performance}

Annual net herbage accumulation (HA) of dryland perennial ryegrass pastures observed in research trials in Victoria ranges between 8 and 14 t DM/ha (Grainger 1992; Jacobs et al. 1999). However, average pasture DM consumed on farms is between 5 and 7 t/ha per annum (Garcia \& Fulkerson 2005). Top-end performance on-farm is in the range 9 to $11 \mathrm{t} \mathrm{DM}$ consumed per ha/ year, comparable to performance achieved in research trials (e.g. $8.7 \mathrm{t} \mathrm{DM} /$ ha with $225 \mathrm{~kg} \mathrm{~N} / \mathrm{ha}$, McKenzie et al. 2003; $11.0 \mathrm{t} \mathrm{DM/ha} \mathrm{with} \mathrm{rapid} \mathrm{spring} \mathrm{grazing,}$ McKenzie et al. 2006).

Farm survey data from the early 1990s showed that, across the range $4-9 \mathrm{tDM} / \mathrm{ha}$ consumed per year, each 
Figure 1 Predicted (from 'DairyMod') mean monthly pasture growth rates for Terang, southwest Victoria (mean average annual rainfall $796 \mathrm{~mm}$ ) compared against monthly feed requirements for autumncalving dairy herds stocked at $1.5,2.0$ and 2.5 cows per hectare.

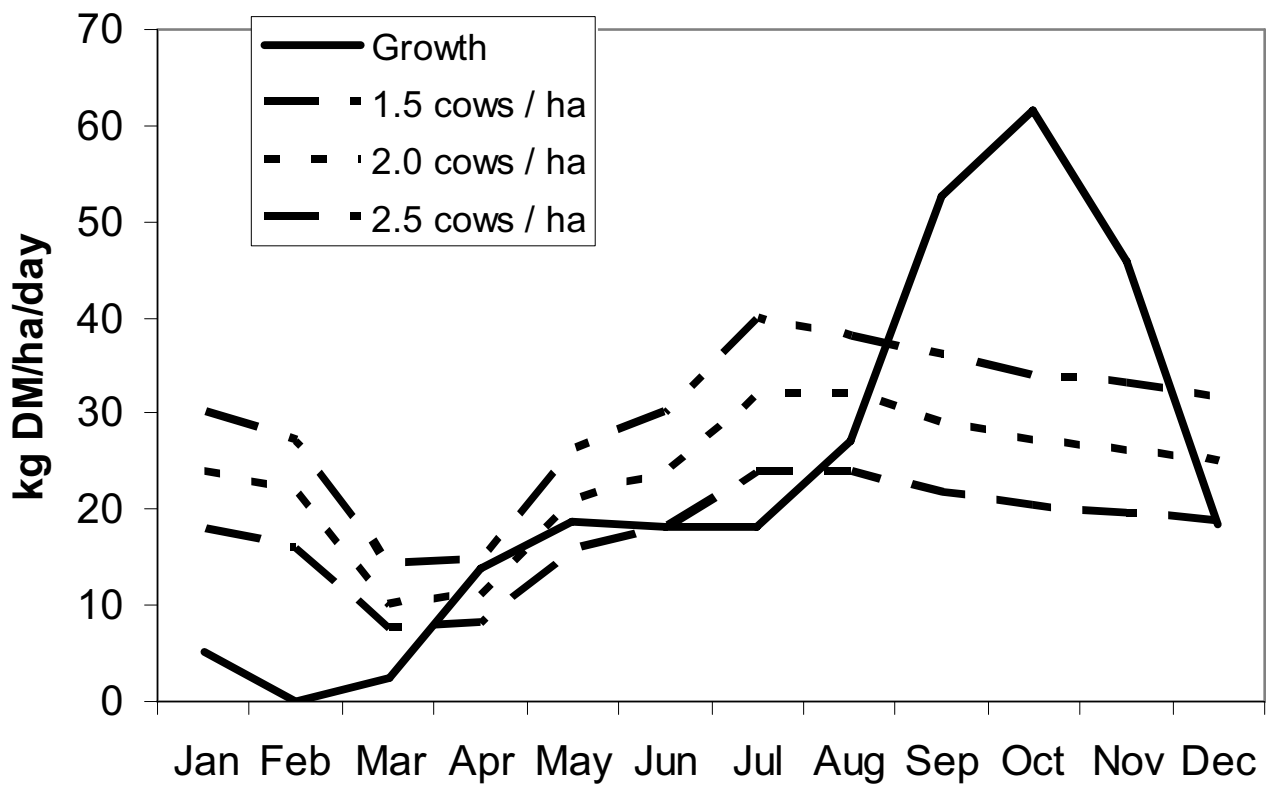

additional tonne of pasture dry matter grown and consumed per hectare increased the gross margin by $\$ 180 /$ ha (O'Brien 1994). Thus, for farmers currently achieving $5-7$ t pasture DM consumption per hectare, profitability can be increased significantly by applying tried and true practices such as renovating pastures, increasing soil fertility, and subdivision to control grazing rotation and increase utilisation efficiency. However for farmers already managing their ryegrass pastures well, the question arises: where will the next step-ups in productivity come from?

\section{How Can We Get More? A Review}

Doyle and Kelly (1998) reported that farm surveys in northern Victoria in the 1990s recorded similar levels of pasture growth to those recorded in the 1970s and 1980s. If this is so (and similar conclusions have been reached in New Zealand e.g. Hodgson 1990; Crush et al. 2006), then the ability of dairy farm businesses to increase milk production per hectare using perennial ryegrass as the main feed base may be seriously limited in the future.

Crush et al. (2006) concluded that alternative plant germplasm will be needed to raise the efficiency of conversion of solar energy into milksolids production in the New Zealand dairy industry. 'Southern Dairy Systems' considered alternative plants for the southern Australia dairy industry by reviewing available information on plant performance and using simulation modelling.

Alternative perennial grasses such as tall fescue, cocksfoot, phalaris and prairie grass are options for complementing or replacing perennial ryegrass. Nie et al. (2004) found that mixtures of tall fescue, cocksfoot and phalaris resulted in lower HA compared to perennial ryegrass in the establishment year, but higher HA in subsequent years. Total annual HA was more consistent over three sites and 4 years from the mixture compared to perennial ryegrass. Tharmaraj et al. (2005a) compared the agronomic performance of a range of pasture types and crops at three locations representing the major soil and climatic regions of southwest Victoria for 3 years. A mixture of tall fescue, chicory, white clover and red clover showed potential to shift the seasonal distribution of forage supply more into the summer compared to perennial ryegrass while also yielding improvements in total annual HA. This mixture produced $25-30 \%$ of total annual HA in the summer months across all three sites, whereas the control treatment produced only $15-$ $20 \%$ of total annual HA in summer. Simultaneously, Tharmaraj et al. (2005b) observed similar milk production potential of cows grazing the tall fescue-based mixture compared to perennial ryegrass in winter and spring, but superior production in summer and autumn due to differences in plant nutritive value and the likely negative effects of ryegrass endophyte toxicosis in the perennial ryegrass pasture in summer and autumn. Tall fescue appears to be a useful plant for dairy systems in southern Australia provided it is grown on heavier soil types and well-managed to maintain green leaf and control pasture mass. 
Cocksfoot, phalaris and prairie grass are not sown to any great extent at present and further studies are required to quantify their potential.

Brassica species have been used in southeast Australia for many years and are grown on approximately $70 \%$ of dryland dairy farms in southern Victoria and Tasmania, with turnips accounting for the majority (Moate et al. 1996). Traditionally, they have been sown as part of pasture renovation programs with a secondary role of producing feed in summer and early autumn. Surveys show that DM yields can vary widely. For example Jacobs et al. (2001) recorded crop yields ranging from 0.4 to $19.2 \mathrm{t} \mathrm{DM} /$ ha across 142 farms in southwest Victoria in 2000. More consistent yields will require coupling better performing areas of the farm to use of $\mathrm{N}$ fertiliser and dairy effluent. An advantage of brassica crops is their high nutritive value compared with many other summer feeds. Jacobs et al. (2001) found the average metabolisable energy (ME) content was 13.7 $\mathrm{MJ} / \mathrm{kg} \mathrm{DM}$, with the crude protein (CP) content of leaves averaging $15.4 \%$ and roots $13.9 \%$. Moate et al. (1998) concluded that turnips have the potential to replace barley in the rations of dairy cows in mid lactation without adversely affecting milk production.

There are opportunities to grow tropical (C4) grasses in southeast Australia, although DM yields are often lower than those observed in warmer climates and where irrigation is provided. The tropical species that could be used range from single harvest maize and sorghums to multi graze species such as millet and forage sorghums. The use of maize is limited to heavier soils in districts with a long growing season such as Gippsland where a wide range in DM yields has been observed (7 to $20 \mathrm{t}$ $\mathrm{DM} /$ ha, G. O'Brien unpublished data). Typically these crops average $10.0-10.5 \mathrm{MJ} \mathrm{ME} / \mathrm{kg} \mathrm{DM}$ and $8 \% \mathrm{CP}$, values similar to those observed for irrigated maize in northern Victoria (Pritchard 1987).

Forage sorghums include sudan grasses, sorghum $\mathrm{x}$ sudan hybrids and sweet sorghum hybrids. Few studies have been undertaken in dryland areas of southern Australia to determine the potential of these crops for dairying. McRae (1983) reported DM yields for forage sorghums in south Gippsland ranging from 3.2 to $10.1 \mathrm{t}$ $\mathrm{DM} / \mathrm{ha}$, but did not state which species were measured. Temperate millets such as Japanese and Shirohie millet should be better adapted to dryland conditions in southern Australia than many of the other C4 species. They can provide early summer feed, although sowing early will impinge upon spring pasture growth for either grazing or forage conservation. Furze \& Shovelton (1984) reported an average dryland millet yield of $5.2 \mathrm{t} \mathrm{DM} / \mathrm{ha}$ compared with $12.6 \mathrm{t} \mathrm{DM} /$ ha from irrigated crops. Eckard et al. (2001) grew Shirohie millet in northwest Tasmania and reported average DM yields of $3.9 \mathrm{t} \mathrm{DM} /$ ha over the 2-year trial. The ME of the millet ranged from 10.7 to $11.3 \mathrm{MJ} / \mathrm{kg} \mathrm{DM}$ whilst CP values were above $20 \%$. Jacobs \& Ward (unpublished data) observed DM yields from millet ranging from 6 to $12 \mathrm{t} \mathrm{DM} /$ ha in southwest Victoria with ME and CP values of around $10 \mathrm{MJ} / \mathrm{kg}$ DM and 13\% respectively. These values, whilst not as high as those observed for brassica crops, do indicate potential for millet to contribute to the diet of lactating dairy cows in summer.

Promising results from cereals grown for whole-crop silage in New Zealand (de Ruiter et al. 2002) have stimulated interest in these crops in southern Australia. To date, little systematic research has been carried out to identify the most promising species and cultivars, and determine their yield potentials and management requirements. The shorter spring season in southern Australia compared to New Zealand raises questions in terms of the ability of such crops to reach the grain fill stage required for silage. A further consideration is that if such crops remain in situ until grain fill, it is unlikely that a summer crop could be planted as soil moisture levels could restrict germination.

\section{Simulation Modelling}

Chapman et al. (2005) used simulation models and financial analysis tools to investigate the potential productivity and economic outcomes from incorporating different forage options into dryland dairy farms in Victoria. They simulated 'base' systems using perennial ryegrass pastures and management policies typical of farm businesses at the Top $40 \%$ or Top $10 \%$ benchmark levels of the industry (measured in terms of economic performance) in southwest Victoria (Terang district, mean annual rainfall $796 \mathrm{~mm}$ ) and Gippsland (Ellinbank, mean annual rainfall $1085 \mathrm{~mm}$ ). 'DairyMod' (Johnson et al. 2003) was used to simulate mean pasture growth curves using 40 years of climate data. This information was then incorporated into 'UDDER' (Larcombe 1989) which was used to simulate the production system including major management inputs (supplementary feeding, $\mathrm{N}$ fertiliser use, silage conservation, grazing rotation etc.) and outputs (milk solids). The costs of all inputs and the income received from milk sales were then analysed in 'Red Sky' using benchmark information on farm assets to estimate operating profit and return on assets. Different forages were then incorporated into these simulations and the effects on productivity and profit compared to the base system. Forage options investigated included annual ryegrass grown as a winter crop on $10 \%$ of farm area, winter cereal grown on $10 \%$ or $15 \%$ of farm area, turnips grown as a summer crop on $10 \%$ or $15 \%$ of farm area, a double cropping program on $15 \%$ of farm area (winter cereal followed by turnips at Terang, or annual ryegrass followed by maize at Ellinbank), and summer- 
Table 1 Physical and economic data for a range of forage systems and different farm types (Top 40\% or Top $10 \%$ ) at Terang in southwest Victoria, and Ellinbank in Gippsland, as estimated using 'DairyMod' and 'UDDER' simulation models and the financial analysis program 'Red Sky'. Effective farm area simulated was 125 ha for Terang and 100 ha for Ellinbank. 'Double cropping' = winter cereal followed by turnips for Terang, and annual ryegrass followed by maize for Ellinbank, on 15\% of farm area. 'Summer-active pasture' $=$ tall fescue on $100 \%$ of farm area for both sites.

\begin{tabular}{|c|c|c|c|c|c|c|}
\hline & \multicolumn{2}{|c|}{ 'Base' ryegrass } & \multicolumn{2}{|c|}{ Double cropping } & \multicolumn{2}{|c|}{ Summer-active pasture } \\
\hline & Top $40 \%$ & Top $10 \%$ & Top $40 \%$ & Top $10 \%$ & Top $40 \%$ & Top $10 \%$ \\
\hline \multicolumn{7}{|l|}{ Terang } \\
\hline Peak milking cow numbers & 225 & 281 & 225 & 281 & 225 & 281 \\
\hline Stocking rate at peak, cows/ha & 1.8 & 2.25 & 1.8 & 2.25 & 1.8 & 2.25 \\
\hline Total home grown forage consumed, t DM/ha & 6.7 & 8.6 & 8.0 & 10.2 & 7.6 & 9.6 \\
\hline Home grown forage as $\%$ total diet & 63.2 & 64.5 & 73.6 & 70.5 & 69.0 & 66.0 \\
\hline Milk solids, kg/cow & 413 & 448 & 434 & 456 & 432 & 451 \\
\hline Milk solids, kg/ha & 766 & 1,007 & 806 & 1,058 & 802 & 1,045 \\
\hline Operating profit \$/effective ha & 693 & 1,170 & 845 & 1,306 & 907 & 1,322 \\
\hline Return on assets \% & 6.3 & 9.3 & 7.6 & 10.4 & 8.1 & 10.5 \\
\hline \multicolumn{7}{|l|}{ Ellinbank } \\
\hline Peak milking cow numbers & 215 & 252 & 215 & 252 & 215 & 252 \\
\hline Stocking rate at peak, cows/ha & 2.15 & 2.52 & 2.15 & 2.52 & 2.15 & 2.52 \\
\hline Total home grown forage consumed, t DM/ha & 7.8 & 9.7 & 10.3 & 11.9 & 9.3 & 11.3 \\
\hline Home grown forage as $\%$ total diet & 61.6 & 61.6 & 78.7 & 72.6 & 74.3 & 72.5 \\
\hline Milk solids, kg/cow & 394 & 434 & 405 & 442 & 394 & 429 \\
\hline Milk solids, kg/ha & 875 & 1,129 & 898 & 1,148 & 875 & 1,116 \\
\hline Operating profit \$/effective ha & 775 & 1,502 & 861 & 1,459 & 915 & 1,650 \\
\hline Return on assets \% & 5.5 & 9.6 & 6.1 & 9.3 & 6.4 & 10.2 \\
\hline
\end{tabular}

active pasture (tall fescue-based). Results from the most promising options (double cropping and summer-active pasture) are shown in Table 1.

Across all of the forage options considered, the estimated improvement in average forage consumption over the effective farm area was in the range $0.5-2.5 \mathrm{t}$ $\mathrm{DM} / \mathrm{ha} /$ year for Top $40 \%$ businesses and $0.9-2.2 \mathrm{t}$ $\mathrm{DM} / \mathrm{ha} /$ year for Top $10 \%$ businesses (e.g. Table 1). In general, within a farm type, each additional tonne of home grown forage consumed per hectare as a result of changing the forage base yielded an additional $\$ 70-$ 110 /ha of operating profit. Note, this is over-and-above the gains made by improving base ryegrass pasture consumption (e.g. O'Brien 1994), and therefore assumes that the potential of ryegrass is already being fully exploited. The models also assumed excellent management of all complementary pastures or crops in order to achieve high end forage consumption rates (7 $10 \mathrm{t} \mathrm{DM} /$ ha for brassicas, $12-14 \mathrm{t} \mathrm{DM} /$ ha for winter cereals grown for whole crop silage).

The literature review revealed many gaps in knowledge of the agronomy, management, and yield potential of these and other forage options. These gaps must be filled, and the potential of complementary forage systems demonstrated in commercial farm businesses, if they are to be successfully adopted within the industry. The important issue of inter-annual variation in climate and associated business risk must also be addressed, since climate variability is a key feature of the environment for agriculture in Australia. Using the same modelling procedures described above, Kenny et al. (2005) concluded that forage systems incorporating double cropping and/or tall fescue returned more consistent profit in the face of late autumn breaks or early cessation of spring growth compared to systems reliant on perennial ryegrass. However, more information is needed from commercial business across a range of years to better understand the impact of the interaction between forage base and climatic conditions on production and profit.

\section{Conclusions}

The target of $20 \mathrm{t} \mathrm{DM} / \mathrm{ha}$ set for the Southern Dairy Systems project was deliberately ambitious. While $20 \mathrm{t}$ $\mathrm{DM} / \mathrm{ha}$ may be achievable on a proportion of the effective farm area using double cropping with high inputs, $12-14 \mathrm{t} \mathrm{DM} / \mathrm{ha}$ consumed per year as an average across the grazing area is a more realistic aim for dryland dairy farms. This will still be difficult and will require the use of other plants that complement perennial ryegrass. Research data on the yield potential and management requirements of candidate crop and pasture species for southern Australia conditions is urgently required. Critically, information on how best to integrate complementary forages into whole farm feeding systems to realise improvements in profit with manageable business and environmental risk must be gathered from both research trials and commercial farm businesses to assist the top end of the industry to move 
'beyond perennial ryegrass'. Whether or not the productivity and profit targets suggested here (eg. Table 1) can be met with home grown forage remains to be seen. However, the challenge must be taken up if the industry is to continue to exploit its comparative advantage of low cost production and remain competitive in global markets.

\section{REFERENCES}

Anon, 2005. Australian Dairy Industry in Focus 2005. Dairy Australia. ISSN 1448-9392.

Chapman, D.F.: Kenny, S.; Beca, D. 2005. Alternative feedbase systems for southern Australia dairy farms. 1. Predicted pasture/crop consumption and farm financial performance. p. 461. In: $\mathrm{XX}^{\text {th }}$ International Grassland Congress: Offered papers. Eds. O’Mara, F.P.; Wilkins, R.J.; 'tMannetje, L.; Lovett, D.K.; Rogers, P.A.M.; Boland, T.M. Wageningen Academic Publishers, Wageningen..

Crush, J.R.; Woodward, S.L.; Eerens, J.P.J.; MacDonald, K.A. 2006. Growth and milksolids production in pastures of older and more recent ryegrass and white clover cultivars under dairy grazing. New Zealand Journal of Agricultural Research 49: 119-135.

De Ruiter, J.M.; Hanson, R.; Hay, A.S.; Armstrong, K.W.; Harrison-Kirk, R.D. 2002. Whole crop cereals for grazing and silage: balancing quality and quantity. Proceedings of the New Zealand Grassland Association 64: 181-189.

Doyle, P.T.; Kelly, K.B. 1998. The Victorian dairy industry -improving performance. pp. 119-127. In: Proceedings of the 9th Australian Agronomy Conference.

Eckard, R.J.; Salardini, A.A.; Hannah, M.; Franks, D.R. 2001. The yield, quality and irrigation response of summer forage crops suitable for a dairy pasture renovation program in north western Tasmania. Australian Journal of Experimental Agriculture 41: 37-44

Fulkerson, W.; Doyle P. 2001. The Australian dairy industry. Department of Natural Resources and Environment, Kyabram, Victoria. 56pp. ISBN 07311 47650

Furze, W.R.; Shovelton, J.B. 1984. A review of Victorian summer fodder crop experiments. Department of Agriculture, Victoria. Research Project Series No. 174. Department of Agriculture, Melbourne.

Garcia, S.C.; Fulkerson, W.J. 2005. Opportunities for future Australian dairy systems: a review. Australian Journal of Experimental Agriculture 45:1041-1055.

Grainger, C. 1992. Feed production and utilisation pasture production and utilisation in southern Australia. pp. 119-127. In: Dairy Horizons - The challenge for extension. Proceedings of a Conference at La Trobe University, November 1992.
Hodgson, J. 1990. Plants for grazing systems. Proceedings of the New Zealand Society of Animal Production 50: 29-34.

Kenny, S.; Chapman, D.F.; Beca, D. 2005. Alternative feedbase systems for southern Australia dairy farms. 2. Seasonal variation. p. 462. In: XXth International Grassland Congress: Offered papers. Eds. O'Mara, F.P.; Wilkins, R.J.; 'tMannetje, L.; Lovett, D.K.; Rogers, P.A.M.; Boland, T.M. Wageningen Academic Publishers, Wageningen..

Jacobs, J.L.; Rigby, S.E.; McKenzie, F.R.; Ward, G.N. 1999. Changes in botanical composition and nutritive characteristics of pasture, and nutrient selection by dairy cows grazing rainfed pastures in western Victoria. Australian Journal of Experimental Agriculture 39: 419-428.

Jacobs, J.L.; Ward, G.N.; McDowell, A.M.; Kearney, G.A. 2001. A survey on the effect of establishment techniques, crop management, moisture availability and soil type on turnip dry matter yield and nutritive characteristics in western Victoria. Australian Journal of Experimental Agriculture 41: 743-751.

Johnson, I.R.; Chapman, D.F.; Parsons, A.J.; Eckard, R.J.; Fulkerson, W.J. 2003. DairyMod: A biophysical model of the Australian dairy system. Proceedings of the Australian Farming Systems Conference, Toowoomba, September 2003 (www.afsa.asn.au/).

Larcombe, M.T. 1989. The effects of manipulating reproduction on the productivity and profitability of dairy herds which graze pasture. PhD thesis, University of Melbourne.

McKenzie, F.R.; Jacobs, J.L.; Kearney, G. 2003. Longterm effects of multiple applications of nitrogen fertiliser on grazed dryland perennial ryegrass / white clover dairy pastures in south-west Victoria. 2. Growth rates, dry matter consumed, and nitrogen response efficiencies. Australian Journal of Agricultural Research 54: 471-476.

McKenzie, F.R.; Jacobs, J.L.; Kearney, G. 2006. Effects of spring grazing on dryland perennial ryegrass/white clover dairy pastures. 1. Pasture accumulation rates, dry matter consumed yield and nutritive characteristics. Australian Journal of Agricultural Research 57: 543554.

McRae C. 1983. Crucifer crops in Victoria. In: Fodder crops for profit. Proceedings of the Grassland Society of Victoria 24th Annual Conference. Grassland Society of Victoria, Parkville, Victoria.

Moate, P.J.; Roche, J.R.; Durling, P. 1996. Fodder turnips on Gippsland dairy farms. Pp 141-142. In: Soils Plants and Animals - The Big Picture. Proceedings of the Grassland Society of Victoria 37th Annual Conference. Grassland Society of Victoria, Mornington, Victoria. Moate, P.J.; Dalley, D.E.; Martin, K.; Grainger, C. 1998. 
Milk production responses to turnips fed to dairy cows in mid-lactation. Australian Journal of Experimental Agriculture 38: 117-123.

Nie, Z.N.; Chapman, D.F.; Tharmaraj, J.; Clements, R. 2004. Effects of pasture species, management, and environment on the productivity and persistence of dairy pastures in south west Victoria. 1. Herbage accumulation and seasonal growth pattern. Australian Journal of Agricultural Research 55: 625-636.

O’Brien, G. (ed.) 1994. Pasture management for dairy farmers. Gippsland and Western Victoria. Department of Agriculture Victoria, East Melbourne. ISBN 07306 47889

Pritchard, K.E. 1987. Yield and quality irrigated summer fodder crops in Northern Victoria. Australian Journal of Experimental Agriculture 27: 817-823.

Tharmaraj, J.; Chapman, D.F.; Nie, Z.N. 2005a. Seasonal herbage accumulation of different dairy pasture types in southern Australia. p. 460. In: XXth International Grassland Congress: Offered papers. Eds. O'Mara, F.P.; Wilkins, R.J.; 'tMannetje, L.; Lovett, D.K.; Rogers, P.A.M.; Boland, T.M. Wageningen Academic Publishers, Wageningen.

Tharmaraj, J.; Chapman, D.F.; Nie, Z.N.; Lane, A.P. 2005b. Milk production potential of different dairy pasture types in southern Australia. p. 135. In: XXth International Grassland Congress: Offered papers. Eds. O’Mara, F.P.; Wilkins, R.J.; 'tMannetje, L.; Lovett, D.K.; Rogers, P.A.M.; Boland, T.M. Wageningen Academic Publishers, Wageningen. 